\title{
POLA ARGUMENTASI SISWA DALAM MENYELESAIKAN SOAL SISTEM PERSAMAAN LINEAR TIGA VARIABEL (SPLTV)
}

\author{
K. Ayu Dwi Indrawati' ${ }^{1)}$, Baiq Rika Ayu Febrilia ${ }^{2 *}$ \\ ${ }^{1)}$ Pasca Sarjana Pendidikan Matematika, Universitas Pendidikan Ganesha \\ ${ }^{2)}$ Prodi Pendidikan Matematika, FPMIPA, IKIP Mataram \\ "rika.febrilia@gmail.com
}

\begin{abstract}
Abstrak
Penelitian ini bertujuan untuk mendeskripsikan pola argumentasi siswa pada tingkat kemampuan yang berbeda yaitu tinggi, sedang dan rendah. Penelitian ini termasuk penelitian kualitatif deskriptif dengan melibatkan 3 siswa X Jurusan Tata Boga 1 yang terdiri dari 2 perempuan dan 1 laki-laki. Pada penelitian ini pengumpulan data menggunakan 2 soal tes (soal benar salah dan soal cerita) dan dibantu dengan wawancara untuk memastikan jawaban siswa. Alat analisis yang digunakan untuk menganalisis pola argumentasi siswa adalah gabungan antara pola argumentasi Toulmin dan pola argumentasi Mc. Neill \& Krajcik. Hasil penelitian menunjukan bahwa siswa dengan tingkat kemampuan tinggi memilik pola argumentasi claim, evidence, reasoning dan rebuttal untuk soal 1, sedangkan pada soal 2 siswa memiliki pola data, claim, evidence dan reasoning. Pada siswa dengan tingkat kemampuan sedang, siswa memiliki pola argumentasi claim, evidence dan reasoning untuk soal 1, sedangkan pada soal 2 siswa memiliki argumentasi data, claim, evidence dan reasoning. Pada siswa dengan tingkat kemampuan rendah, siswa memiliki pola argumentasi claim, evidence, reasoning untuk soal 1, sedangkan untuk soal 2 siswa memiliki pola argumentasi data, claim, evidence dan reasoning.
\end{abstract}

Kata Kunci: Pola argumentasi, Penyelesaian soal, SPLTV.

\section{PENDAHULUAN}

Dalam pembelajaran matematika, siswa tidak hanya belajar mengenai bagaimana cara menyelesaikan soal tetapi juga belajar mengenai cara berargumentasi (Wulandari, 2016). Kemampuan siswa berargumentasi dipengaruhi oleh peran guru dalam memberdayakan siswa untuk membenarkan suatu pernyataan matematika (Aberdein \& Dove, 2013). Argumentasi menunjukkan kemampuan mengemukakan alasan secara logis yang disertai dengan data dan dukungan teori yang memadai baik dalam bentuk lisan maupun tulisan (Soekisno, 2015). Menurut Fadillah (2015) argumentasi berkaitan dengan kemampuan komunikasi seseorang untuk memberikan alasan yang berbasis pada fakta-fakta untuk membuat kesimpulan dan sering digunakan dalam bukti matematika. Argumentasi tidak 
dapat dikategorikan benar atau salah tetapi sah atau tidak, sehingga kemampuan seseorang tidak menjamin keabsahan suatu argumentasi (Laamena, 2018).

Dalam matematika, argumentasi sangat diperlukan untuk pemahaman konsep siswa (Erduran dkk, 2004) dan agar siswa dapat menjelaskan secara logis dan memutuskan cara atau penyelesaian yang tepat untuk menyelesaikan masalahnya (Sari, 2015). Pada penyelesaian soal matematika siswa dituntut untuk merumuskan masalah, memilih strategi yang tepat, menggunakan argumenargumen mengenai kebenaran dari solusi yang ia berikan dalam proses penyelesaian soal (Hartatian, 2011).

Terdapat beberapa pola argumentasi siswa dapat digunakan mengidentifikasi pola argumentasi siswa, yaitu pola argumentasi Toulmin dan pola argumentasi Mc. Neill \& Krajcik. Pola argumentasi Toulmin terdiri dari 6 aspek yaitu (1) data: siswa mampu mengidentifikasi informasi dan mampu menyatakan informasi apa saja yang ada pada tiap langkah penyelesaian, (2) claim: siswa mampu menyatakan langkah mana yang benar dan langkah mana yang salah, (3) warrant: siswa mampu memberikan alasan mengenai claim yang dikeluarkan siswa, (4) backing: siswa mampu memberikan bukti untuk mendukung warrant, (5) qualifier: siswa mampu menunjukan tingkat keyakinan akan claim yang diberikan, (6) rebuttal: siswa mampu menolak pernyataan dan menjeleaskan kondisi dimana pernyataan tersebut tidak berlaku (Handayani, 2015). Pola argumentasi Mc. Neill \& Krajcik terdiri dari 3 aspek, yaitu (1) claim: siswa mampu menyatakan langkah mana yang benar dan langkah mana yang salah, (2) evidence: siswa mampu menunjukan data

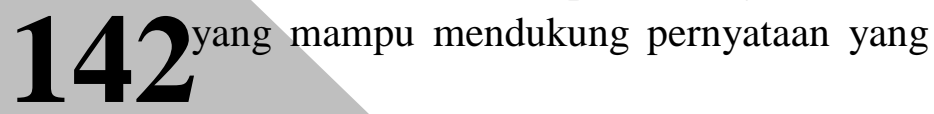

dikemukakan, (3) reasoning: siswa mampu memberikan alasan sebagai pembenaran dari pernyataan yang disertai dengan bukti (Pritasari, 2016).

Penelitian ini menggabungankan pola argumentasi yang dikembangkan oleh Toulmin dan pola argumentasi Mc. Neill \& Krajcik sebagai alat untuk menganalisis argumentasi siswa. Hal ini bertujuan untuk mengetahui pola siswa dalam berargumentasi berdasarkan pada 5 aspek yang dapat dilihat pada Tabel 1. Beberapa aspek ini dipilih berdasarkan pertimbangan untuk mendapatkan secara rinci seperti apa pola siswa berargumentasi dalam menyelesaikan suatu masalah. Aspek warrant, backing dan qualifier tidak digunakan dalam penelitian ini karena warrant, backing, qualifier telah terwakilkan oleh aspek evidence dan reasoning.

Tabel 1.Pola argumentasi dan indikatornya

\begin{tabular}{|c|c|}
\hline $\begin{array}{c}\text { Pola } \\
\text { Argumentasi }\end{array}$ & Indikator \\
\hline Data & $\begin{array}{l}\text { Siswa mampu } \\
\text { mengidentifikasi informasi } \\
\text { dan mampu menyatakan } \\
\text { informasi apa saja yang } \\
\text { ada pada soal dan pada tiap } \\
\text { langkah penyelesaian. }\end{array}$ \\
\hline Claim & $\begin{array}{l}\text { Siswa mampu memberikan } \\
\text { pernyataan untuk } \\
\text { menjawab permasalahan } \\
\text { yang diberikan. }\end{array}$ \\
\hline Evidence & $\begin{array}{l}\text { Siswa mampu menunjukan } \\
\text { data yang mampu } \\
\text { mendukung pernyataan } \\
\text { yang dikemukakan. }\end{array}$ \\
\hline Reasoning & $\begin{array}{l}\text { Siswa mampu memberikan } \\
\text { alasan sebagai pembenaran } \\
\text { dari pernyataan yang } \\
\text { disertai dengan bukti }\end{array}$ \\
\hline Rebuttal & $\begin{array}{lr}\text { Siswa mampu } & \text { menolak } \\
\text { pernyataan } & \text { dan } \\
\text { menjeleaskan } & \text { kondisi } \\
\text { dimana } & \text { pernyataan } \\
\text { tersebut tidak berlaku. }\end{array}$ \\
\hline
\end{tabular}


Selama ini tingkat kemampuan argumentasi siswa masih tergolong rendah, terlihat dari rendahnya keinginan siswa untuk memberikan tanggapan mengenai pembelajaran yang telah diajarkan, memberikan tanggapan atas jawaban yang diberikan oleh orang lain, agar apa yang sedang mereka pelajari menjadi lebih bermakna (Pugalee, 2001). Rendahnya kemampuan argumentasi siswa di Indonesia ditandai dengan kesulitan siswa dalam menyelesaikan soal yang tidak seperti yan biasa diajarkan. Hal ini disebabkan karena biasanya siswa hanya mengikuti perintah/arahan yang diberikan oleh guru dalam menyelesaikan suatu masalah. Jika dihadapkan kepada tugas/masalah yang memiliki kesulitan sedikit lebih tinggi siswa perlu menghubungkan informasi-informasi yang ada menggunakan penalaran untuk menyelesaikan tugas/masalah yang diberikan (OECD, 2015).

Argumentasi erat kaitannya dengan penalaran dan proses berpikir. Argumentasi merupakan fondasi untuk mengemukakan suatu alasan (berpikir kritis) disertai dengan data dan dukungan teori yang memadai dari suatu masalah matematika (berpikir logis) (Seokisno, 2015). Terutama pada materi Sistem Persamaan Linear Tiga Variabel (SPLTV), siswa dituntut untuk memiliki kemampuan dalam berargumentasi, sehingga dapat membantu siswa dalam memecahkan masalah dengan menggunakan penalaran (Anisah, 2013), maka penting bagi guru untuk melatih kemampuan argumentasi siswa salah satunya kemampuan argumentasi siswa pada materi SPLTV. Siswa sering mengalami miskonsepsi dalam membuat model matematika dari soal cerita yang diberikan dan siswa kadang sulit menentukan metode mana yang akan digunakan dalam menyelesaikan soal.
Oleh karena itu penting bagi guru untuk melatih kemampuan argumentasi siswa agar siswa lebih bebas dalam memilih, tanpa keragu-raguan dan ketidaktegasan dalam memecahkan suatu masalah, bahkan siswa dapat mengajukan solusi yang masuk akal dan siswa mampu memahami konsep dari SPLTV. Berdasarkan uraian diatas, maka fokus penelitian ini adalah untuk mendeskripsikan pola argumentasi siswa pada tingkat kemampuan yang berbeda yaitu tinggi, sedang dan rendah.

\section{METODE PENELITIAN}

Jenis penelitian ini adalah deskriptif kualitatif untuk menggambarkan pola argumentasi siswa dalam menyelesaikan soal SPLTV. Subjek penelitian ini adalah siswa kelas $\mathrm{X}$ Tata Boga 1 SMKN 4 Mataram sebagai subjek penelitian. Siswa yang menjadi subjek penelitian berjumlah 3 orang yang terdiri dari 1 siswa laki-laki dan 2 siswa perempuan. Pemilihan ketiga subjek ini didasarkan pada tingkat kemampuan matematika siswa (tingkat kemampuan rendah, tingkat kemampuan sedang dan tingkat kemampuan tinggi) dan juga kemampuan komunikasi siswa. Kedua hal tersebut digunakan untuk mendapatkan pola argumentasi dari siswa dengan kemampuan matematika yang berbeda-beda berdasarkan tingkat kemampuan matematikanya.

Dalam penelitian ini, peneliti merupakan instrumen utama dan dibantu dengan beberapa instrumen lainnya. Instrumen pendukung yang digunakan dalam pengumpulan data terdiri dari 2 soal tes dan juga pedoman wawancara. Kedua instrumen pendukung tersebut telah melalui validasi ahli yang berjumlah 3 orang. Dalam pengumpulan data, pada penelitian ini menggunakan soal tes dan wawancara. 
Soal tes yang diberikan berbentuk soal benar salah dan soal cerita. Hal ini bertujuan untuk membandingkan pola argumentasi yang siswa berikan untuk soal dengan bentuk soal yang jarang siswa jumpai dan soal yang memiliki bentuk seperti biasa siswa jumpai. Wawancara digunakan untuk mengonfirmasi hasil pekerjaan siswa pada kedua tes yang telah diberikan.

Teknik analisis data yang dilakukan pada penelitian in yaitu dengan mengkoding setiap argumentasi siswa pada transkrip hasil wawancara yang sesuai dengan indikator pola argumentasi yang tercantum pada Tabel 1. Data-data yang telah didapatkan kemudian dikelompokan dan dituliskan dalam bentuk teks yang bersifat naratif.

\section{HASIL DAN PEMBAHASAN \\ Rancangan Soal}

Soal yang diberikan terdiri dari 2 soal, yaitu soal nomor 1 adalah soal yang telah dilengkapi dengan beberapa langkah penyelesaian dan siswa diminta untuk menentukan langkah mana yang benar atau salah dari setiap langkah yang ada pada penyelesaiannya soal tersebut disertai dengan alasan mengapa bisa langkah tersebut dinyatakan salah atau benar seperti yang terlihat pada Gambar 1.

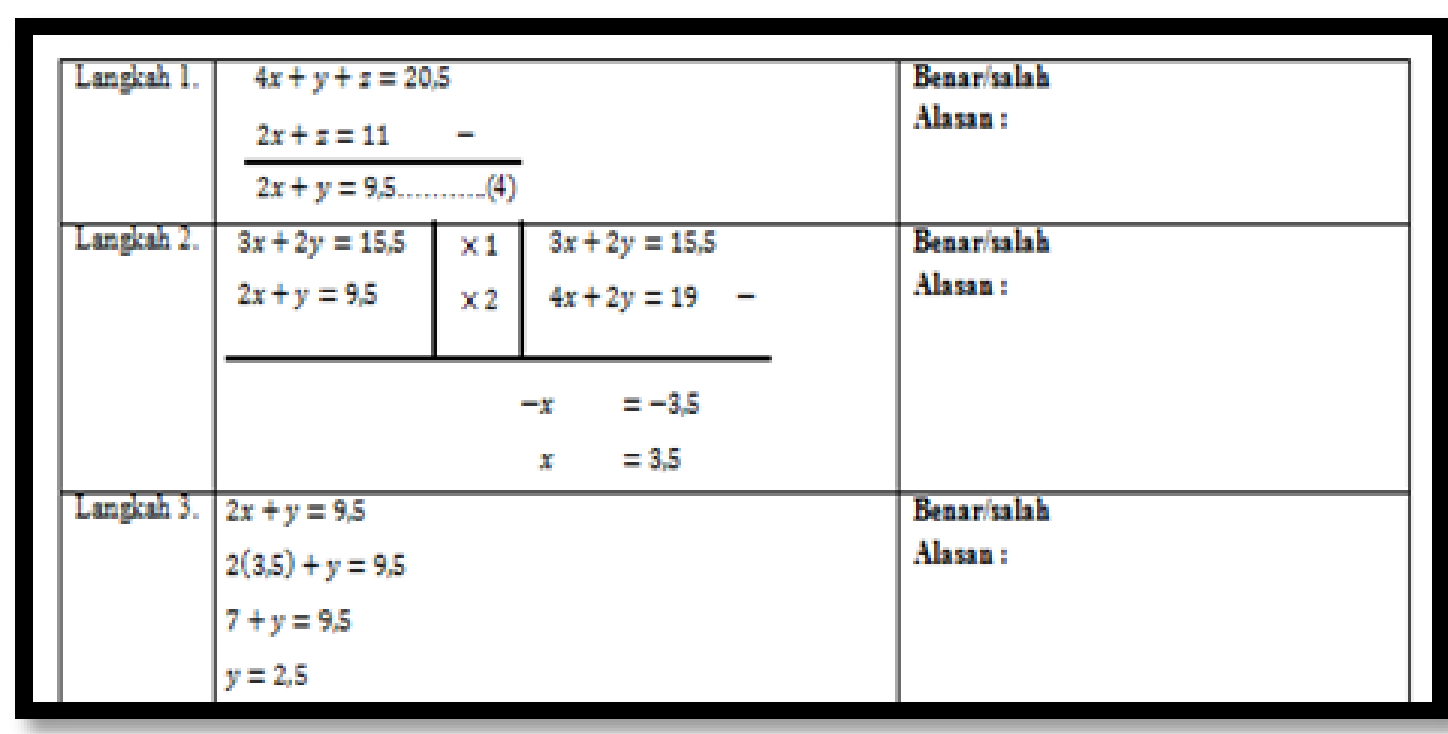

Gambar 1. Soal tes benar salah

Penggunaan soal benar/salah seperti ini bertujuan untuk mengetahui pemahaman konsep dan penguasaan materi SPLTV berdasarkan argumentasi yang diberikan siswa. Menyelesaikan pernyataan benar salah adalah proses yang digunakan oleh peneliti matematika untuk kegiatan menemukan (Easdown, 2012). Ini artinya, dengan membiasakan siswa dalam menyelesaikan soal tipe benar salah, maka siswa juga dibiasakan untuk mengkaji lebih jauh keberlakuan suatu langkah/aturan melalui kegiatan penemuan. Soal nomor 2 berbentuk soal cerita seperti yang biasa siswa jumpai seperti pada Gambar 2. Penggunaan 2 soal yang berbeda ini bertujuan untuk mengetahui seperti apa perbedaan siswa dalam menyelesaikan soal jika soal yang diberikan telah memiliki penyelesaian dan yang belum memiliki penyelesaian. 
Ibu Sonia membeli $5 \mathrm{~kg}$ telur, $2 \mathrm{~kg}$ daging, dan $1 \mathrm{~kg}$ udang dengan harga Rp. $265,000,00$.

Ibu Endang membeli $3 \mathrm{~kg}$ telur dan $1 \mathrm{~kg}$ daging dengan harga Rp. 126.000,00. Ibu Sinta

membeli $3 \mathrm{~kg}$ daging dan $2 \mathrm{~kg}$ udang dengan harga Rp. 320,000,00. Jika bu Ani membeli 2

$\mathrm{kg}$ telur, $1 \mathrm{~kg}$ daging, dan $1 \mathrm{~kg}$ udang ditempat yang sama, berapakah yang harus ia

bayarkan?

\section{Gambar 2. Soal cerita SPLTV}

Dalam pembelajaran matematika, sangat diperlukan kemampuan merancang soal, tugas dan aktivitas oleh guru. Perancangan soal, tugas dan aktivitas akan membantu siswa dalam mengaitkan konsep satu dan konsep lainnya dan memperdalam pemahamannya terhadap konsep tersebut (Febrilia \& Winarti, 2018; Juliangkary \& Febrilia 2018). Dengan demikian, kemampuan siswa dalam berargumentasi juga akan meningkat seiring dengan meningkatnya pemahaman siswa terhadap suatu konsep matematika.

\section{Pola Argumentasi}

Ketiga siswa tersebut diwawancara untuk mengetahui pola argumentasi yang digunakan siswa dalam menyelesaikan soal dan perbedaan pola argumentasi siswa terhadap soal-soal yang memiliki bentuk yang berbeda seperti kedua soal yang diberikan. Kemudian hasil wawancara tersebut dianalisis menggunakan indikator yang ada pada Tabel 1, sehingga didapatkan perbedaan pola argumentasi ketiga siswa dalam menyelesaikan soal 1 dan soal yang 2 yang diberikan seperti yang dapat dilihat pada Tabel 2.
Tabel 2. Pola argumentasi siswa pada tingkat kemampuan tinggi, sedang dan rendah dalam menyelesaikan soal SPLTV

\begin{tabular}{ccccccc}
\hline Pola & \multicolumn{2}{c}{ SKT } & \multicolumn{2}{c}{ SKS } & \multicolumn{2}{c}{ SKR } \\
\cline { 2 - 7 } Argumentas & Soal & Soal & Soal & Soal & Soal & Soal \\
i & $\mathbf{1}$ & $\mathbf{2}$ & $\mathbf{1}$ & $\mathbf{2}$ & $\mathbf{1}$ & $\mathbf{2}$ \\
\hline Data & 0 & 1 & 0 & 1 & 0 & 3 \\
\hline Claim & 15 & 10 & 10 & 7 & 11 & 7 \\
\hline Evidence & 8 & 5 & 6 & 5 & 2 & 0 \\
\hline Reasoning & 9 & 6 & 6 & 6 & 4 & 10 \\
\hline Rebuttal & 1 & 0 & 0 & 0 & 0 & 0
\end{tabular}

Berdasarkan Tabel 2, maka pola argumentasi ketiga siswa dapat diuraikan seperti berikut :

Pola Argumentasi Siswa Pada Tingkat Kemampuan Tinggi Dalam Menyelesaikan Soal SPLTV

Pada awalnya siswa terlihat kebingungan untuk menentukan langkah mana yang benar dan langkah mana yang salah. Hal ini dikarenakan siswa tidak terbiasa dihadapkan dengan soal yang berbentuk benar salah dan menuntut siswa untuk berargumentasi dalam penyelesaian soalnya. Dalam mengerjakan soal 1, siswa tidak menunjukkan bahwa dia telah mengidentifikasi data yang ada pada soal baik dalam bentuk tulisan maupun secara lisan. Namun, siswa beberapa kali membuat perhitungan ulang pada masing-masing 
langkahnya. Hal tersebut dapat dilihat pada Gambar 3.

$$
\begin{aligned}
& 2 x+z=11 \quad|-5|-10 x-5 z=-55 \\
& -5 x-2 z=-25,5|2|-10 x-4 z=-51 \\
& \frac{-}{-z=-4} \\
& z=4
\end{aligned}
$$

Gambar 3. Perhitungan ulang yang siswa lakukan pada langkah 5

Melalui apa yang telah dilakukan oleh siswa ini, diduga siswa tersebut telah mampu dalam mengidentifikasi informasi yang ada pada soal yang diberikan tanpa mengungkapkan secara langsung mengenai informasi apa yang telah ia dapatkan. Hal ini dimungkinkan terjadi karena saat mengerjakan soal tipe benar salah, siswa lebih fokus untuk meninjau benar atau tidaknya dan alasan dari tiap langkah yang dipertanyakan dalam soal.

Berbeda halnya dengan soal 2, siswa terlebih dahulu mengidentifikasi data atau informasi yang ada pada soal seperti apa yang diketahui dan apa yang ditanyakan. Hal ini dapat dilihat pada cuplikan wawancara antara peneliti $(\mathrm{P})$ dengan siswa dengan tingkat kemampuan tinggi (SKT) berikut ini.

$P$ : Berdasarkan soal tersebut informasi apa saja yang Anda dapatkan?

$S K$ : Ibu Sonia membeli $5 \mathrm{~kg}$ telur, 2

$T \quad \mathrm{~kg}$ daging, dan $1 \mathrm{~kg}$ udang dengan harga Rp. 265.000,00. Ibu Endang membeli $3 \mathrm{~kg}$ telur dan $1 \mathrm{~kg}$ daging dengan harga Rp. 126.000,00. Ibu Sinta membeli $3 \mathrm{~kg}$ daging dan $2 \mathrm{~kg}$ udang dengan harga $R p$. 320.000,00.

$P \quad$ : Menurut anda, apa yang hendak dicari dalam soal tersebut?

SK : Jika bu ani membeli $2 \mathrm{~kg}$ telur, 1
$T$

$\mathrm{kg}$ daging, dan $1 \mathrm{~kg}$ udang ditempat yang sama, berapakah yang harus ia bayarkan?

Berdasarkan wawancara di atas, diperoleh fakta bahwa ketika siswa dimintai penjelasan mengenai apa yang diketahui dan ditanyakan dalam soal, mereka cenderung untuk menuliskan informasi apa adanya (Nisa dkk, 2016) dan persis seperti yang tertulis dalam soal dalam bentuk kalimat yang sama (Vendiagrys dkk, 2015).

Untuk soal 1, siswa mampu membuat claim setelah membaca langkah-langkah yang ditanyakan. Pembuatan claim oleh siswa berkemampuan tinggi disertai dengan menunjukkan data (evidence) dan memberikan alasan sebagai bukti bahwa pernyataan yang siswa berikan benar adanya (reasoning). Pada cuplikan wawancara berikut, dapat menggambarkan kondisi ketika siswa memberikan alasan beserta data yang mendukung pertanyaan mengapa langkah 1 dapat siswa katakan salah.

\section{$P$ : Kalau kamu mengatakan langkah 1 salah, bagaimana perbaikannya? \\ SK : Eh langkah 1 sebenarnya $T$ benar. Ini kan 3 variabel sedangkan ini 2 variabel, sama-sama ada $z$ nya, tinggal dikurangi kemudian dihilangkan $z$ nya. Jadi kita menghilangkan $z$ nya untuk membentuk persamaan baru yaitu persamaan 4.}

Claim yang diberikan siswa berupa pernyataan metode mana yang akan siswa gunakan dalam menyelesaikan soal. Dalam pembuatan claim yan diberikan siswa didukung oleh fakta-fakta yang sudah pernah dipelajari sebelumnya oleh siswa. Bentuk dari evidence yang siswa berikan berupa data-data yang didapatkan dari soal dan data yang diberikan berbenda dengan 
K. Ayu Dwi Indrawati dan Baiq Rika Ayu Febrilia: Pola Argumentasi Siswa Dalam Menyelesaikan Soal Sistem Persamaan Linear Tiga Variabel (SPLTV).

FIBONACCI : Jurnal Pendidikan Matematika dan Matematika. Vol. 5 (2), pp: 141 - 154.

data yang diberikan untuk mengidentifikasi

informasi (data), sedangkan reasoning yang diberikan berupa penjelasan dari proses perhitungan yang siswa lakukan. Ketiga hal tersebut juga dapat dilihat dari salah satu transkrip wawancara berikut ini dimana siswa menjelaskan alur penyelesaian soal mulai dari pemilihan metode sampai mendapatkan persamaan baru.

$$
\begin{aligned}
& \text { SK : Caranya adalah kita } \\
& T \text { menggunakan eliminasi dan } \\
& \text { substitusi. Dari ketiga } \\
& \text { persamaan tersebut saya } \\
& \text { menggunakan persamaan } 1 \\
& \text { dan persamaan } 2 \text { untuk } \\
& \text { mengeliminasi yang a. } \\
& \text { Persamaan } 1 \text { semua dikalikan } \\
& \text { 3, menjadi } \\
& 5 a \times 3=15 a \text {, } \\
& 2 b \times 3=6 b \text {, } \\
& c \times 3=3 c \text {, } \\
& 265.000 \times 3=795.000 \text {. } \\
& 3 a \times 5=15 a \text {, } \\
& b \times 5=5 b \text {, } \\
& 126.000 \times 3=630.000 \text {. } \\
& 6 b-5 b=1 b \text {, } \\
& \text { c nya turun, } \\
& 795.000-630.000=165.000 \\
& \text { Menghasilkan persamaan } \\
& \text { baru } \\
& b+3 c=165.000
\end{aligned}
$$

Pada soal 1 juga ditemukan adanya rebutttal yang diberikan siswa berupa penjelasan mengenai kondisi yang tidak memungkinkan untuk mencari nilai variabel. Salah satu contohnya ditunjukan pada cuplikan wawancara berikut.

$P \quad:$ Ini kan mengunakan persamaan 2 dan persamaan 3 untuk menghilangan $z$ nya, kalau menggunakan persamaan lain bisa tidak? Seperti persamaan 1 dan 2 atau 1 dan 3?

SK : Bisa sih, tapi yang dihilangkan $T \quad$ bukan variable $z$ nya tapi variable lain. Karena kalau kita mau menghilangkan variable $z$ harus menggunakan persamaan yang ada variable $z$ nya juga.

Berbeda halnya dengan soal 2, pada soal ini tidak ditemukan rebuttal yang diberikan siswa. Siswa hanya menjawab soal sesuai pemahaman dari pembelajaran sebelumnya tanpa memberikan keterangan kondisi seperti apa yang tidak memungkinkan untuk menemukan jawaban tersebut. Jika berdasarkan hasil analisis yang telah dilakukan, siswa lebih lancar menyelesaikan soal yang berbentuk soal cerita pada umumnya seperti yang ditunjukan pada soal 2.

Pola Argumentasi Siswa Pada Tingkat Kemampuan Sedang Dalam Menyelesaikan Soal SPLTV

Pada siswa dengan tingkat kemampuan sedang, siswa juga tidak menunjukan secara lisan maupun tulisan bahwa ia telah melakukan identifikasi pada tiap langkah sebelum membuat claim. Siswa ini langsung membuat claim setelah ditanya langkah mana yang siswa anggap salah dan langkah mana yang siswa anggap benar. Setelah memberikan claim,siswa kemudian menunjukan data (evidence) yang digunakan untuk mendukung pernyataan siswa seperti yang dapat dilihat pada cuplikan wawancara antara peneliti (P) dengan siswa berkemampuan sedang (SKS) berikut ini.

$P \quad:$ Coba perhatikan soal dan langkah-langkah 
penyelesaiannya! Menurut kamu, langkah mana yang salah dan langkah mana yang benar dari langkahlangkah penyelesaian ini?

\section{SK : Langkah 1 benar karena}

$S \quad$ yang dieliminasi itu samasama $z$ nya dan di persamaan 2 dan persamaan 3 sama-sama punya $z$ dengan koefisien 1.

Berbeda dari soal 1, pada soal 2 siswa terlebih dahulu mengidentifikasi informasi (data) yang ada pada soal seperti apa yang diketahui dan yang ditanyakan sebelum memberikan claim seperti yang dapat dilihat pada cuplikan wawancara berikut ini.

\section{$P$ : Berdasarkan soal tersebut informasi apa saja yang anda dapatkan? \\ SK : Diketahui Ibu Sonia membeli $S \quad 5 \mathrm{~kg}$ telur, $2 \mathrm{~kg}$ daging, dan 1 $k g$ udang dengan harga $R p$. 265.000. Ibu Endang membeli $3 \mathrm{~kg}$ telur dan $1 \mathrm{~kg}$ daging dengan harga Rp. 126.000. $\mathrm{Ibu}$ Sinta membeli $3 \mathrm{~kg}$ daging dan $2 \mathrm{~kg}$ udang dengan harga Rp. 320.000 \\ Ditanyakan, jika bu ani membeli $2 \mathrm{~kg}$ telur, $1 \mathrm{~kg}$ daging, dan $1 \mathrm{~kg}$ udang ditempat yang sama, berapakah yang harus ia bayarkan?}

Setelah mengidentifikasi informasi yang ada, barulah siswa memberikan claim, namun claim yang diberikan siswa juga berbeda dari soal sebelumnya. Claim yang diberikan siswa untuk soal 2 berupa pernyataan mengenai langkah apa yang akan digunakan dalam menyelesaikan soal yang diberikan. Claim yang diberikan siswa diikuti juga dengan evidence dan reasoning yang mampu mendukung claim yang diberikan siswa. Bentuk claim, evidence dan reasoning yang diberikan siswa pada soal 2 dapat dilihat pada salah satu cuplikan wawancara berikut ini.

$$
\begin{aligned}
\text { SKS : Misalnya telur }=a, \text { daging } \\
=b, \text { dan udang }=c \\
\text { (i) } 5 a+2 b+c=265.000 \\
\text { (ii) } 3 a+b=126.000 \\
\text { (iii) } 3 b+2 c=320.000
\end{aligned}
$$

Pertama, saya mengeliminasi a melalui persamaan 1 dan persamaan 2. Nanti masingmasing persamaan dikalikan suatu bilangan supaya jadinya sama. Diperoleh pada persamaan 1

$5 a \times 3=15 a$, $2 b \times 3=6 b$, $c \times 3=3 c$,

$265.000 \times 3=795.000$.

Persamaan 2

$3 a \times 5=15 a$, $b \times 5=5 b$, $126.000 \times 3=630.000$.

Terus dieliminasi, yang pertama dieliminasi itu kan a jadinya persamaan itu a nya habis. Jadinya $6 b-5 b=1 b, c$ nya turun, $795.000-630.000=165.000$ . Jadinya $b+3 c=165.000$ sebagai persamaan ke 4.

Berdasarkan hasil wawancara dan analisis hasil pekerjaan siswa, diperoleh informasi bahwa siswa melakukan kesalahan dalam membuat permisalan. Siswa memisalkan $a$ sebagai telur, $b$ sebagai daging dan $c$ sebagai udang.Padahal seharusnya, a merupakan harga satu butir telur, $b$ merupakan harga 1 $\mathrm{kg}$ daging dan $c$ adalah harga $1 \mathrm{~kg}$ udang. Kesalahan ini merupakan kesalahan tipe konsep variabel yang sering dijumpai pada saat siswa membuat permisalan dalam 
K. Ayu Dwi Indrawati dan Baiq Rika Ayu Febrilia: Pola Argumentasi Siswa Dalam Menyelesaikan Soal Sistem Persamaan Linear Tiga Variabel (SPLTV).

FIBONACCI : Jurnal Pendidikan Matematika dan Matematika. Vol. 5 (2), pp: 141 - 154.

permasalahan bentuk aljabar dan persamaan linear (Herutomo \& Saputro, 2014).Contoh pekerjaan siswa yang sesuai dengan penjabaran dan cuplikan wawancara di atas dapat dilihat pada Gambar 4.

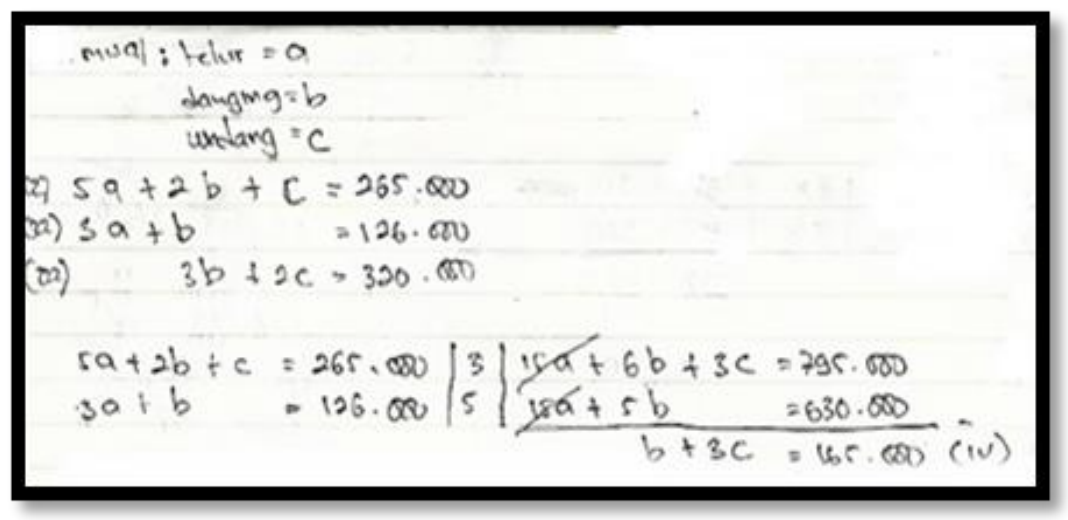

Gambar 4. Hasil pekerjaan siswa pada soal 2

Pada soal 1, siswa pada tingkat ini juga memberikan reasoning seperti yang dilakukan pada soal 2. Sebelum membuat reasoning, siswa terlebih dahulu memeriksa ulang langkah-langkah yang ada pada soal 1 dengan cara menghitung kembali untuk membuktikan kebenaran dari claim yang siswa berikan. Hal tersebut dapat dilihat pada cuplikan wawancara berikut.

$P \quad: \quad \begin{aligned} & \text { Langkah } 4 \text { ini menurutmu } \\ & \text { bagimana? Benar atau } \\ & \text { salah? }\end{aligned}$
Benar,

SKS : Benar, karena disini itu menghilangkan y nya jadinya benar hasilnya itu $-5 x+2 z-$ 25,5 .
Untuk langkah 4 sampai langkah ke 6, siswa menyatakan bahwa jawaban pada ketiga langkah tersebut benar, namun setelah siswa memeriksa jawabannya siswa menyadari telah melakukan kesalahan perhitungan pada langkah 4 dan berdampak ke langkah-langkah selanjutnya. Dari kedua kegiatan diatas, diketahui bahwa siswa mampu mengevaluasi kembali argumentasi yang telah siswa berikan (Herman, 2007). Berdasarkan perhitungan ulang yang dilakukan oleh siswa, siswa mampu memberikan perbaikan pada langkahlangkah yang siswa anggap salah. Hal ini seperti yang dapat dilihat pada Gambar 5.

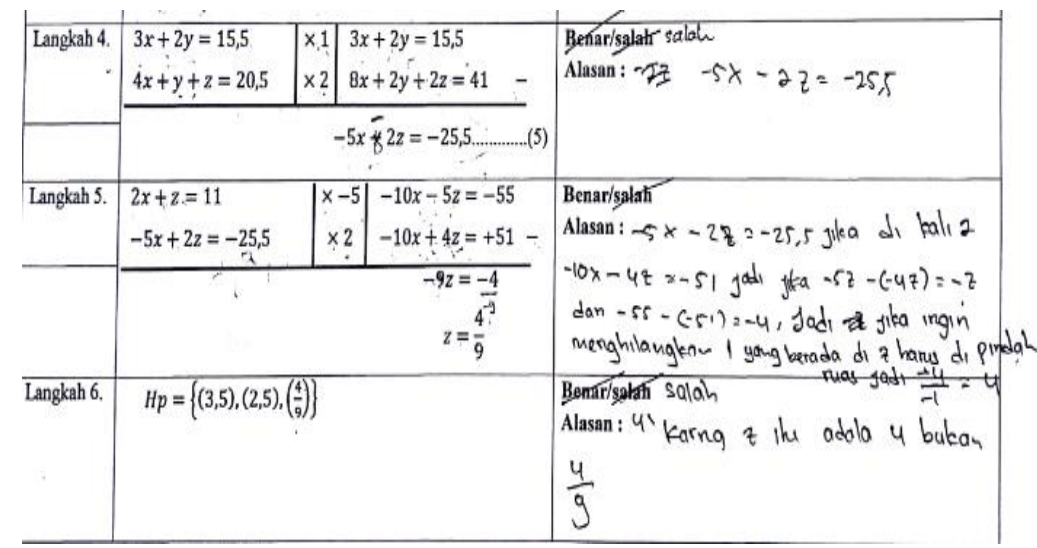

Gambar 5. Aspek reasoning yang diberikan siswa dalam menyelesaikan soal 1 
Dari kedua soal yang dikerjakan, siswa tidak memberikan rebuttal baik pada soal 1 maupun soal 2. Hal ini disebabkan karena siswa hanya mampu menjelaskan kondisi yang terjadi pada soal sehingga claim yang siswa berikan berlaku dan siswa tidak menjelaskan kondisi seperti apa yang membuat claim yang siswa berikan tidak berlaku. Sama halnya seperti yang terjadi pada siswa dengan kemampuan tinggi, siswa pada tingkat ini juga mengalami kesulitan dalam menyelesaikan soal 1 yang berbentuk benar salah dibandingkan dengan soal berbetuk cerita. Hal ini dikarenakan, siswa terbiasa untuk menyelesaikan soal dari awal tanpa dilengkapi dengan langkahlangkahnya. Hal ini dikarenakan, kurangnya kemampuan siswa untuk menyampaikan gagasan yang siswa miliki melalui lisan agar mudah dipahami oleh orang lain (Kurnia, 2011). Dalam menyelesaikan kedua soal tersebut, siswa tidak sepenuhnya menggunakan konsepkonsep yang pernah dipelajari sebelumnya tetapi siswa juga menyelinginya dengan penggunaan intuisi ketika siswa tidak mengetahui beberapa alasan dari pemberian claim yang siswa berikan.

Pola argumentasi siswa pada tingkat kemampuan rendah dalam menyelesaikan soal SPLTV

Sama halnya dengan yang dilakukan siswa pada tingkat kemampuan tinggi dan siswa dengan tingkat kemampuan sedang, siswa pada tingkat ini juga tidak mengidentifikasi apa yang diketahui dan apa yang ditanyakan pada soal 1. Siswa langsung membuat claim setalah melihat langkah-langkah yang ada pada soal. Namun saat dimintai menujukan data ataupun memberikan alasan dari pembuatan claim, siswa mampu menunjukan evidence pahami dari soal. Hanya saja evidence dan reasoning yang siswa berikan kurang lengkap dan kurang kuat untuk dijadikan alasan untuk pembenaran claim yang ia berikan. Hal tersebut dikarenakan lemahnya penalaran siswa untuk mengingat kembali metode-metode yang telah dipelajari sebelumnya dan menghubungkan faktafakta untuk dirangkai agar mampu menyelesaikan permasalah selanjutnya (Hartatiana, 2014). Oleh karena itu, siswa cenderung menggunakan intuisi daripada menggunakan konsep-konsep yang telah dipelajari sebelumnya. Hal tersebut dapat dilihat pada cuplikan wawancara berikut.

$P \quad$ : Bagaimana langkah 2 dari soal ini menurutmu? Apakah benar atau salah?

SKR : Salah ini.

$P \quad$ : Kenapa Anda berpendapat demikian?

SKR : Dia salah dah pokoknya.

$P \quad$ : Iya, tapi alasannya apa sehingga Anda mengatakan ini salah?

SKR : Dia salah dah, feeling saya bilang ini salah.

$P \quad$ : Bagaimana dengan langkah lainnya?

SKR : Ya salah semua.

Pada siswa berkemampuan rendah, ditemukan kesalahan dalam membedakan antara variabel dan persamaan. Siswa juga keliru membedakan ketiga variabel yang ada pada himpunan penyelesaian dengan bilangan desimal yang menjadi nilai dari variabel $x$ dan $y$. Hal ini disebabkan ketika oleh ketika seseorang berargumentasi, ia akan lebih banyak mmberikan alasan untuk membenarkan claim yang diberikan (Stein \& Bernas, 1999). Seperti yang dapat dilihat pada Gambar 6, siswa mampu memberikan claim, evidence, dan resoning hanya saja claim, evidence, dan resoning kurang tepat. 


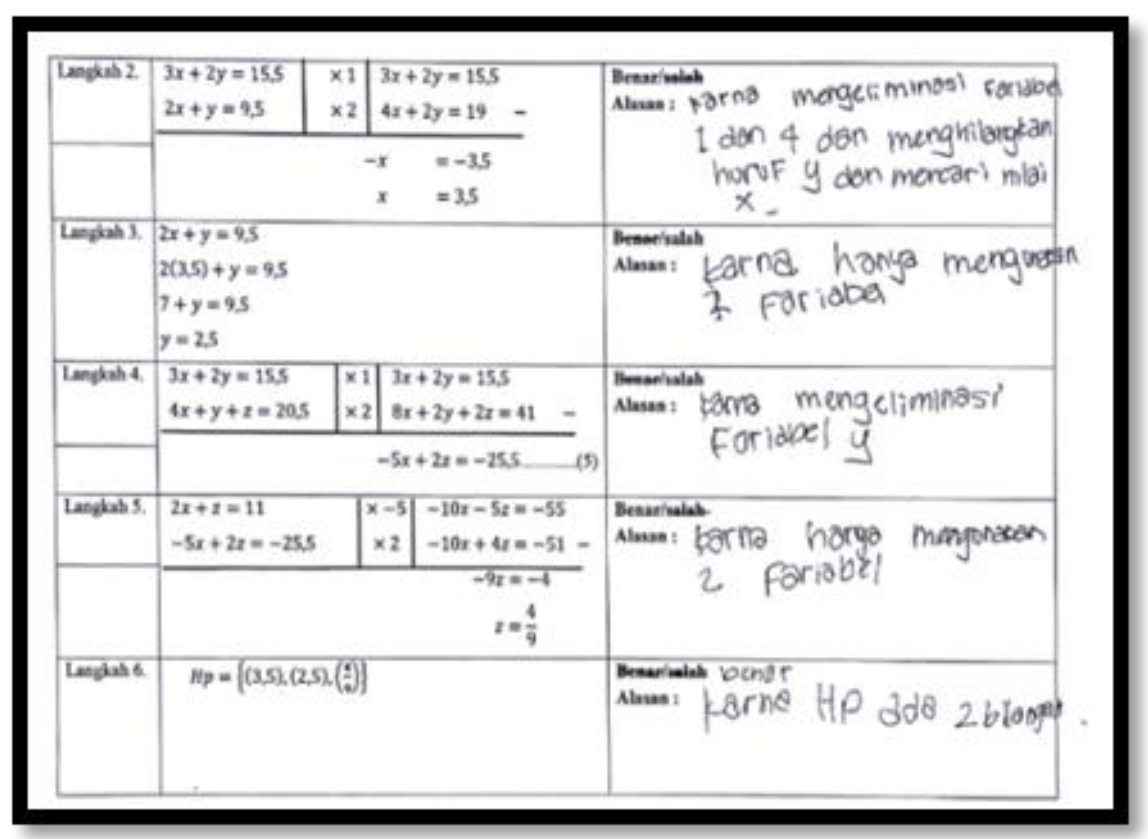

Gambar 6. Aspek claim, evidence, reasoning yang diberikan siswa dalam menyelesaikan soal 1

Untuk soal 2 siswa hanya mampu mengidentifikasi informasi yang ada pada soal. Siswa tidak mampu menyelesaikan soal hingga akhir dan menemukan himpunan penyelesiaannya untuk menjawab pertanyaan pada soal dikarenakan siswa lupa dengan konsepkonsep penyelesaian soal SPLTV. Hal tersebut dapat dilihat pada cuplikan wawancara berikut ini.

$P \quad: \quad$ Bisa kamu tuliskan apa
yang kamu ketahui dan apa
yang ditanyakan dari soal?
SKR $\quad$ Yang diketahui $x=$ telur $y$
$=$ daging dan $z=$ udang.
Ibu Sonia
$=5 x+2 y+1 z=265.000$

Ibu
3x $+y=126.000$.
Ibu
3y $+2 z=320.000$.
Ditanyakan $:$
Ibu Sinta $2 x+y+z=\cdots ?$
Bisa coba diselesaikan tidak
bagaimana cara

$\begin{array}{lll} & & \text { mengerjakan soal ini? } \\ \text { SKR } & : \text { Tidak bisa sepertinya. } \\ P & : & \text { Kenapa? } \\ \text { SKR } & : \text { Soal ini sulit, tidak bisa. } \\ \text { SKR } & : \text { Sulitnya karna dia tiga } \\ & \text { variabel, sehingga tidak } \\ & \text { bisa menggunakan cara, } \\ & \text { bisanya hanya } \\ & \text { menggunakan matriks dan } \\ & \text { saya lupa caranya. } \\ \text { Hasil } & \text { wawancara di atas }\end{array}$
menunjukkan bahwa siswa berkemampuan rendah juga melakukan kesalahan dalam membuat permisalan variabel sama seperti yang ditunjukkan oleh siswa berkemampuan rendah. Hanya saja, pada siswa berkemampuan rendah, dia tidak mampu dalam menyelesaikan permasalahan yang diberikan dengan baik.

Berdasarkan kedua cara siswa dalam menyelesaikan soal tersebut, didapatkan bahwa siswa memberikan alasan yang kurang tepat pada soal 1 disebakan oleh kurangnya kemampuan penalaran siswa sehingga siswa kurang mampu membangun kemampuan dalam 
berargumentasi berdasarkan kaidah dasar matematika (Susilowati, 2016).

\section{SIMPULAN}

Berdasarkan hasil temuan yang telah dibahas di atas, maka dapat diambil beberapa simpulan dari argumentasi yang telah diberikan siswa. Siswa pada tingkat kemampuan tinggi memilik pola argumentasi claim, evidence, reasoning dan rebuttal untuk soal 1 . Untuk soal 2, siswa memiliki pola data, claim, evidence dan reasoning. Dalam proses pengerjaannya siswa menggunakan konsep-konsep dan pengetahuan yang telah ia dapatkan sebelumnya untuk menyelesaikan soal-soal yang diberikan. Pada siswa dengan tingkat kemampuan sedang, siswa memiliki pola argumentasi claim, evidence dan reasoning untuk soal 1. Pada soal 2, siswa memiliki argumentasi data, claim, evidence dan reasoning. Dalam proses penyelesaian soal 1 yang siswa tidak sepenuhnya menggunakan konsep-konsep dan pengetahuan yang telah dimiliki sebelmnya. Terkadang siswa menggunakan intuisi jika siswa tidak mampu memberikan evidence/reasoning secara tepat. Pada siswa dengan tingkat kemampuan rendah, dalam pengerjaan soal 1 siswa memiliki pola argumentasi claim, evidence, dan reasoning, sedangkan untuk soal 2, siswa memiliki pola argumentasi data, claim, evidence dan reasoning. Dalam penyelesaian soal 1 siswa lebih banyak menggunakan intuisi dibandingkan menggunakan pengetahuan yang telah ia pelajari sebelumnya.

\section{DAFTAR PUSTAKA}

Aberdein, A. 2013. The argument of mathematics. I. J. Dove (Ed.). Dordrecht: Springer.
Anisah, A., Zulkardi, Z., \& Darmawijoyo, D. 2013. "Pengembangan Soal Matematika Model PISA Pada Konten Quantity Untuk Mengukur Kemampuan Penalaran Matematis Siswa Sekolah Menengah Pertama”. Jurnal Pendidikan Matematika, Vol. $5(1)$.

Easdown, D. 2012. "The Importance Of True-False Statements In Mathematics Teaching And Learning". Makalah Dalam: The Australian Conference on Science and Mathematics Education (formerly UniServe Science Conference, October 2013.

Erduran, S., Simon, S., \& Osborne, J. 2004. "TAPping into argumentation: Developments in the application of Toulmin's argument pattern for studying science discourse". Science Education. Vol 88(6), pp: 915-933.

Fadillah, A. 2015. Pengaruh model pembelajaran dan kemampuan komunikasi matematika terhadap hasil belajar matematika siswa. FIBONACCI: Jurnal Pendidikan Matematika dan Matematika. Vol 1(2), pp: 1-12.

Febrilia, B. R. A., \& Winarti, D. W. 2018. "Deepening students understanding of triangle topic through 'application'component of ELPSA (Experience, Language, Pictorial, Symbol and Application) framework". In Journal of Physics: Conference Series. Vol. 1088(1), pp: 012085.

Fuadi, R., Johar, R., \& Munzir, S. 2016. "Peningkatkan

Kemampuan Pemahaman Dan Penalaran Matematis Melalui Pendekatan Kontekstual". Jurnal Didaktik Matematika. Vol. 3(1), pp: 47-54.

Handayani, P. 2015. "Analisis Argumentasi Peserta Didik Kelas X Sma Muhammadiyah 1 Palembang 
Dengan Menggunakan Model Argumentasi Toulmin". Jurnal Inovasi dan Pembelajaran Fisika. Vol. 2(1), pp: 60-68.

Hartatiana, H. 2014. "Pengembangan Soal Pemecahan Masalah Berbasis Argumen Untuk Siswa Kelas V Di SD Negeri 79 Palembang". Jurnal Pendidikan Matematika. Vol. 8(2), pp: 76-85.

Herman, T. 2007. "Pembelajaran Berbasis Masalah Untuk Meningkatkan Kemampuan Penalaran Matematis Siswa SMP". Cakrawala Pendidikan. Vol. 1(1), pp: 41-62.

Herutomo, R. A., \& Saputro, T. E. M. 2014. "Analisis Kesalahan Dan Miskonsepsi Siswa Kelas VIII Pada Materi Aljabar". Edusentris, Jurnal Ilmu Pendidikan dan Pengajaran. Vol. 1(2), pp: 173-183.

Inglis, M., Mejia-Ramos, J. P., \& Simpson, A. 2007. "Modelling mathematical argumentation: The importance of qualification". Educational Studies in Mathematics. Vol. 66(1), pp: 3-21.

Juliangkary, E., \& Febrilia, B. R. A. 2018. "Profil guru ditinjau dari permasalahan matematika yang dikembangkan: termasuk rich tasks atau bukan?". JISIP: Jurnal Ilmu Sosial dan Pendidikan. Vol. 2(3).

Kurnia, R. N. 2011. Analisis kemampuan komunikasi matematis siswa kelas VII C SMP Negeri 1 Rogojampi tahun pelajaran 2014/2015. [Online] Tersedia:

http://repository.unej.ac.id/bitstream/ handle/123456789/64048/RIZKA\%2 0NURUL\%20KURNIA.pdf?sequenc $\mathrm{e}=1 \&$ isAllowed $=\mathrm{y} \quad\left[\begin{array}{ll}16 & \text { Desember }\end{array}\right.$ 2019].

Laamena, C. M., Nusantara, T., Irawan, E. B., \& Muksar, M. 2018. "Analysis of the Students' Argumentation based on the level of Ability: Study on the
Process of Mathematical Proof". In Journal of Physics: Conference Series. Vol. 1028(1).

Nisa, H. M., Sa'dijah, C., \& Qohar, A. 2016. "Kemampuan Pemecahan Masalah Matematika Siswa SMK Bergaya Kognitif Field Dependent". Makalah Dalam: Seminar Nasional Matematika dan Pendidikan Matematika, November 2016.

OECD. 2015. PISA 2015 draft mathematics framework. New York: Columbia University.

Pritasari, A. C., \& Dwiastuti, S. 2016. "Improvement Of Argumentation Skill Through Implementation Of Problem Based Learning In X MIA 1 SMA Batik 2 Surakarta In The Academic Year 2014/2015”. Pendidikan Biologi. Vol 8(1).

Pugalee, D. K. 2001. "Writing, Mathematics, And Metacognition: Looking For Connections Through Students' Work In Mathematical Problem Solving". School science and mathematics. Vol 101(5), pp: 236-245.

Sari, E. F. P. 2015. "Pengembangan Soal Matematika Model PISA Untuk Mengetahui Argumentasi Siswa Di Sekolah Menengah Pertama". Jurnal Pendidikan Matematika. Vol. 9(2), pp: 124-147.

Soekisno, R. B. A. 2015. "Pembelajaran Berbasis Masalah Untuk Meningkatkan Kemampuan Argumentasi Matematis Mahasiswa". Infinity Journal. Vol. 4(2), pp: 120-139.

Stein, N. L., \& Bernas, R. 1999. "The Early Emergence Of Argumentative Knowledge And Skill". Foundations of argumentative text processing. Vol. 5, pp: 97-116.

Susilowati, J. P. A. 2016. "Profil Penalaran Siswa SMP Dalam Pemecahan 
Masalah Matematika Ditinjau Dari Perbedaan Gender". JRPM (Jurnal Review Pembelajaran Matematika). Vol. 1(2), pp: 132-148.

Vendiagrys, L., \& Junaedi, I. 2015. "Analisis kemampuan pemecahan masalah matematika soal setipe TIMSS berdasarkan gaya kognitif siswa pada pembelajaran model problem based learning". Unnes
Journal of Mathematics Education Research. Vol. 4(1).

Wulandari, W., Darmawijoyo, D., \& Hartono, Y. 2016. "Pengaruh pendekatan pemodelan matematika terhadap kemampuan argumentasi siswa kelas VIII SMP Negeri 15 Palembang". Jurnal Pendidikan Matematika Sriwijaya. Vol. 10(1), pp: 114-126. 